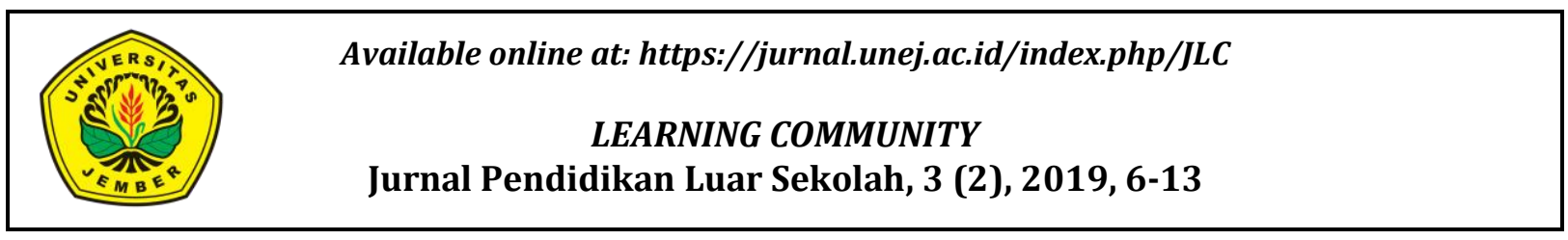

\title{
Evaluasi Program Model CIPP Pada Pelatihan Menjahit Di LKP Kartika Bawen
}

\author{
Nia Mei Istiyani, Utsman \\ Jurusan Pendidikan Luar Sekolah, Fakultas Ilmu Pendidikan Universitas Negeri Semarang \\ Jl. Kampus Timur, Sekaran, Kec. Gn. Pati, Kota Semarang, Jawa Tengah 50229, Indonesia \\ Email: niamei39@gmail.com, utsman@mail.unnes.ac.id
}

\begin{abstract}
Abstrak
Tujuan penelitian mendeskripsikan evaluasi program menggunakan Model CIPP yang meliputi evaluasi context, input, process, product di LKP Kartika. Pendekatan penelitian menggunakan kualitatif. Subjek dalam penelitian ini terdiri dari 1 pengelola, 1 instruktur, 2 warga belajar. Teknik pengumpulan data dengan cara wawancara, observasi, dan dokumentasi. Keabsahan data menggunakan triangulasi sumber dan metode. Teknik analisis data dengan reduksi data, penyajian data dan kesimpulan. Disimpulkan bahwa evaluasi context yang diselenggarakan oleh LKP Kartika sesuai dengan kebutuhan dan tujuan warga belajar. Evaluasi input, yang meliputi komponen warga belajar, instruktur, kurikulum, materi pelatihan, pendanaan, sarana dan prasarana sudah sesuai dengan apa yang diharapkan. Evaluasi proses yang meliputi kegiatan warga belajar, kegiatan instruktur, strategi pembelajaran dan partisipasi warga belajar, semuanya sudah berjalan dengan lancar didalam proses pelatihan menjahit di LKP Kartika. Evaluasi Product dalam pelatihan ini meliputi ketercapaian program, hasil belajar dan dampak program sudah sesuai yang diharapkan warga belajar dan lembaga pelatihan.
\end{abstract}

Kata Kunci: evaluasi program; LKP; menjahit; model CIPP; pelatihan

\section{Evaluation of the CIPP Model Program in Tailoring Training At LKP Kartika Bawen}

\begin{abstract}
The objectives of the study describe the evaluation of the program using the CIPP Model which includes the evaluation of context, input, process, product in LKP Kartika. The research approach is qualitative. Subjects in this study consists of 1 manager, 1 instructor, 2 residents learn. Data collection techniques by interview, observation, and documentation. The validity of the data using source and method triangulation. Data analysis techniques with data reduction, data presentation and conclusions. It was concluded that evaluation of the context of sewing training program organized by LKP Kartika was in accordance with the needs and objectives of the studying population. Evaluation of inputs, which include the components of studying citizens, instructors, curriculum, training materials, funding, facilities and infrastructure are in accordance with what is expected. Evaluation of the process which includes the activities of the learning community, the instructor's activities, the learning strategies and the participation of the studying citizens, has all gone smoothly in the sewing training process at LKP Kartika. Product Evaluation in this training includes the achievement of the program, the learning outcomes and the impact of the program as expected by the learning community and the training institution.
\end{abstract}

Keywords: program evaluation; LKP; sewing; the model CIPP; training 



\section{Learning Community: Jurnal Pendidikan Luar Sekolah, 2 (1), September 2019 - 7}

Nia Mei Istiyani

\section{PENDAHULUAN}

Eko Putro Widoyoko (2009: 9-10) menyatakan bahwa evaluasi program merupakan rangkaian kegiatan yang dilakukan dengan sengaja dan secara cermat untuk mengetahui tingkat keterlaksanaan atau keberhasilan suatu program dengan cara mengetahui efektivitas masing-masing komponennya, baik terhadap program yang sedang berjalan maupun program yang telah berlalu. Sedangkan Ihwan Mahmudi (2011: 15) menyatakan bahwa Evaluasi program adalah langkah awal dalam supervisi, yaitu mengumpulkan data yang tepat agar dapat dilanjutkan dengan pemberian pembinaan yang tepat pula. Evaluasi program sangat penting dan bermanfaat terutama bagi pengambil keputusan. Alasannya adalah dengan masukan hasil evaluasi program itulah para pengambil keputusan akan menentukan tindak lanjut dari program yang sedang atau telah dilaksanakan. Tujuan evaluasi menurut Sudjana (2006:36-46) terdiri atas tujuan umum dan tujuan khusus. Tujuan umum evaluasi program adalah menyediakan atau menyajikan data sebagai masukan bagi pengambilan keputusan tentang program tersebut. Tujuan khusus evaluasi program bermacam ragam, di antaranya sebagaimana diuraikan berikut ini

1) Memberi masukan untuk perencanaan program.

2) Memberi masukan untuk kelanjutan, perluasan, dan penghentian program.

3) Memberi masukan untuk modifikasi program.

4) Memperoleh informasi tentang faktor pendukung dan penghambat program.

5) Memberi masukan untuk motivasi dan pembinan pengelola dan pelaksana program.

6) Memberi masukan untuk memahami landasan keilmuan bagi evaluasi program.

Dalam mengevaluasi program banyak model yang bisa digunakan untuk mengevaluasi suatu program. Meskipun antara satu dengan lainnya berbeda, namun mempunyai tujuan yang sama yaitu melakukan kegiatan pengumpulan data atau informasi yang berkenaan dengan objek yang dievaluasi, yang tujuannya menyediakan bahan bagi pengambil keputusan dalam menentukan tindak lanjut suatu program.Ada beberapa ahli evaluasi program yang dikenal sebagi penemu model evaluasi program. Salah satunya adalah model CIPP yang dikembangkan oleh yang pertama kali di rekomendasikan oleh Stufflebeam pada tahun 1970. Menurut Widoyoko (2009: 181) konsep evaluasi CIPP ditawarkan oleh Stufflebeam dengan pandangan bahwa tujuan penting evaluasi adalah bukan membuktikan, tetapi untuk memperbaiki. Model evaluasi CIPP membagi empat jenis kegiatan yang disesuaikan dengan nama model evaluasinya, yaitu konteks, input, proses, dan produk. Keempat jenis kegiatan tersebut merupakan komponen dari proses sebuah program kegiatan yang dilaksanakan oleh suatu lembaga. Menurut Undang-Undang Nomor 20 Tahun 2003 tentang Sistem Pendidikan Nasional, ada beberapa ayat yang mengatur tentang kursus, khususnya pada pasal 26 ayat (4) dan ayat (5). Kursus dan pelatihan diselenggarakan bagi masyarakat yang memperlukan bekal pengetahuan, keterampilan, kecakapan hidup, dan sikap untuk mengembangkan diri, mengembangkan profesi, bekerja, usaha mandiri, dan/atau melanjutkan pendidikan yang lebih tinggi. Kursus dan pelatihan dapat diselenggarakan oleh satuan pendidikan nonformal, yaitu: Lembaga Kursus dan Pelatihan (LKP), PKBM, Sanggar Kegiatan Belajar (SKB), Penyelenggaraan Lembaga pemerintah desa, dan Lembaga lain yang sejenis. Bekal keterampilan yang ditawarkan oleh berbagai lembaga tersebut diharapkan dapat menambah dan memperkuat kompetensi masyarakat, sehingga dapat mempersiapkan diri memasuki dunia kerja. Lembaga kursus dan Pelatihan (LKP) Kartika Bawen menyelenggarakan program pelatihan menjahit, dengan adanya program pelatihan tersebut diharapkan warga belajar mampu mengembangkan keterampilannya.

\section{METODE}

Penelitian ini menggunakan pendekatan kualitatif. Lokasi penelitian adalah di Lembaga Kursus dan Pelatihan Kartika Bawen, Jl. Palagan No. 26 Bawen Kabupaten Semarang. Subjek dalam penelitian ini adalah pengelola lembaga, tutor, dan warga belajar yang terlibat dalam program kursus menjahit di LKP Kartika. 


\section{Learning Community: Jurnal Pendidikan Luar Sekolah, 3 (2), September 2019 - 8}

Nia Mei Istiyani

Pemilihan subjek penelitian ini adalah agar informasi yang ingin diperoleh dapat diakui kebenarannya. Penelitian ini memfokuskan pada: Evaluasi Progam Model CIPP Pada Pelatihan Menjahit Di LKP Kartika Bawen, meliputi evaluasi context, evaluasi input, evaluasi process dan evaluasi product. Sumber data dalam penelitian ini data primer adalah data yang diperoleh secara langsung dari informan, yaitu pengelola, instruktur dan warga belajar. Data sekunder ini diperoleh melalui observasi yang didapatkan berupa profil LKP Kartika Bawen. .Dalam penelitian ini teknik pengumpulan data dilakukan dengan menggunakan wawancara, observasi, dan dokumentasi. Tahapan analisis data dalam penelitian ini yaitu reduksi data, penyajiandata dan penyimpulan dan verifikasi, dan kesimpulan akhir. Reduksi data yaitu data yang diperoleh direduksi, dirangkum, dipilih hal-hal yang pokok, difokuskan pada hal-hal yang penting.Penyajian data dilakukan setelah data direduksi. Data yang diperoleh dikategorisasikan menurut pokok permasalahan. Data yang sudah direduksi dan disajikan secara sistematis akan disimpulkan sementara. Kesimpulan sementara yang dihasilkan biasanya masih kurang jelas, sehingga perlu untuk diverifikasi lagi. Kesimpulan akhir diperoleh berdasarkan kesimpulan sementara yang telah diverifikasi. Kesimpulan akhir ini menghasilkan makna dari data sesuai dengan fokus yang diteliti secara singkat, jelas, dan mudah dipahami. Dalam penelitian ini teknik keabsahan data yang digunakan adalah triangulasi sumber dan triangulasi teknik atau metode

\section{HASIL DAN PEMBAHASAN}

\section{Evaluasi Context}

Menurut Sudjana (2006: 82) menyatakan bahwa kebutuhan pelatihan dan kebutuhan belajar dapat diidentifikasi dari berbagai sumber yaitu dari calon peserta pelatihan, organisasi tempat calon peserta pelatihan bertugas atau bekerja, masyarakat yang menjadi layanan kegiatan calon peserta pelatihan , dan pihak-pihak terkait.

Program kursus menjahit yang diselenggarakan oleh LKP Kartika dirancang agar dapat memenuhi kebutuhan dari warga belajar. Lembaga menyediakan program lalu peserta dapat memilih program apa yang mereka inginkan dan apa yang mereka butuhkan. Berdasarkan penelitian yang peneliti lakukan dilapangan, program yang diselenggarakan oleh LKP Kartika telah sesuai dengan kebutuhan warga belajar. Karena, program yang dilaksanakan telah berdasarkan hasil pemilihan warga belajar yang tentunya itu sesuai dengan keinginan dan kebutuhannya.

Tujuan merupakan keinginan yang akan dicapai. Tujuan ini akan menjadi acuan bagi lembaga yang menyelenggarakan program agar dalam pelaksanaannya dapat mencapai tujuan tersebut. Dalam jurnal internasional Approaches to Evaluation of training : Theory and Practice oleh Eseryel (2002): Evaluation goals involve multiple purposes at different levels. These purposes include of student learning, evaluation of instructional materials, transfer of training, return of investment, and so on. Attaining these multiple purposes may require the collaboration of different people in different parts of an organization. Furthermore, not all goals may be welt defined and some may change.

Tujuan evaluasi melibatkan beberapa tujuan pada tingkat berbeda. Tujuan ini termasuk tujuan belajar siswa, evaluasi bahan ajar (kurikulum), transfer pelatihan (kemampuan), pengembalian invest (feedback), dan sebagainya Tujuan adalah suatu cita-cita yang ingin dicapai dan pelaksanaan suatu kegiatan (Nurhalim, 2012:34). Tujuan merupakan sasaran dimana kegiatan tersebut diarahkan untuk dicapai. Tujuan yang ditetapkan oleh LKP Kartika telah sesuai dengan tujuan dari warga belajar. Sehingga dalam pelaksanaannya, program yang diselenggarakan dapat mencapai tujuan yang telah ditetapkan baik oleh lembaga maupun oleh warga belajar itu sendiri.

\section{Evaluasi Input}

Menurut Djudju Sudjana (2006: 92) peserta didik mempunyai karakteristik yang meliputi atribut fisik yang berupa usia, atribut psikis yang berupa motivasi belajar, dan atribut fungsional yang berupa tingkat pendidikan. Secara keseluruhan dari evaluasi karakteristik warga belajar yang mengikuti program kecakapan hidup menjahit di LKP 


\section{Learning Community: Jurnal Pendidikan Luar Sekolah, 2 (1), September 2019 - 9}

Nia Mei Istiyani

Kartika dari segi pendidikan dan pengalaman yang dimiliki oleh warga belajar terkait dengan program yang diselenggarakan dapat dikatakan cukup mempermudah jalannya proses pembelajaran. Rata-rata usia warga belajar yang mengikuti pembelajaran adalah termasuk usia produktif, yaitu berkisar antara 19-45 tahun. Dengan usia produktif seperti itu akan mempermudah warga belajar dalam menerima materi dan mengikuti pembelajaran. Motivasi warga belajar untuk mengikuti program dapat dikatakan baik. Karena motivasi itu berasal dari dalam diri warga belajar, sehingga membuat mereka lebih terpacu dan bersemangat untuk mengikuti program kecakapan hidup menjahit yang diselenggarakan oleh LKP Kartika.

Latar belakang pendidikan instruktur dan pengalaman kerja yang dimiliki oleh instruktur dapat dikatakan telah sesuai dengan program pelatihan menjahit yang diselenggarakan oleh LKP Kartika. Ikka Kartika (2011: 104) menyebutkan bahwa pelatih/ instruktur/ tutor adalah seseorang yang melayani dan memperlancar aktivitas belajar peserta pelatihan untuk mencapai tujuan berdasarkan pengalaman. Hasil penelitian yang peneliti dapatkan di lapangan telah sesuai dengan pernyataan Ikka Kartika, yaitu tutor yang ada dapat melayani dan memperlancar jalannya aktivitas pembelajaran warga belajar untuk mencapai tujuan. Dengan latar belakang pendidikan dan pengalaman kerja instruktur yang telah sesuai dengan program, dapat membantu memperlancar proses pembelajaran.

Ikka Kartika (2011: 68) menyebutkan bahwa kurikulum adalah seperangkat rencana dan pengaturan mengenai tujuan, isi dan bahan pelajaran, serta cara yang digunakan sebagai pedoman penyelenggaraan kegiatan pembelajaran untuk mencapai tujuan pendidikan tertentu. Kurikulum yang digunakan dalam program kursus menjahit di LKP Kartika mengacu pada kurikulum nasional tentang menjahit. Kurikulum yang ada menyesuaikan dengan kurikulum nasional, agar produk yang dihasilkan dari program dapat memiliki kualifikasi kemampuan yang berkualitas dan memiliki daya saing.

Materi pelatihan merupakan bagian

dari input atau masukan yang perlu diperhatikan. Berdasarkan hasil penelitian bahwa materi pelatihan yang digunakan pada program pelatihan menjahit ialah hasil atau dari instruktur pelatihan. Materi pelatihan pada program pelatihan ini dibuat oleh instruktur pelatihan yang merujuk pada Tujuan Intruksional Khusus yang dirancang oleh penyelenggara program pelatihan. Namun, tidak adanya kontrol dalam materi pelatihan dengan Tujuan Intruksional Khusus ini terjadi. Hal ini dapat kita lihat bahwa penyampaian materi pelatihan diketahui oleh penyelenggara pelatihan ketika instruktur pelatihan menyampaikan materi pelatihan kepada warga belajar.

Hal ini tentunya sependapat dengan instruksi presiden no. 15 tahun 1974 bahwa pelatihan adalah bagian dari pendidikan yng menyangkut proses belajar untuk memperoleh dan meningkatkan ketrampilan di luar sistem yang berlaku dalam waktu yang relatif singkat dan menggunakan metode yang lebih mengutamakan praktik. Selain hal tersebut, Sudjana (2006:43) mengemukakan bahwa mewadahi materi pembelajaran atau pelatihan untuk memenuhi kebutuhan pribadi peserta pelatihan dalam keseluruhan materi yang mencerminkan kebutuhan. Untuk melakukan hal tersebut perlu diperhatikan: (1) upayakan sejauh mungkin supaya materi dapat memenuhi kebutuhan pribadi peserta pelatihan yang diintegrasikan dengan materi pebelajaran untuk memenuhi kebutuhan, (2) apabila hal itu tidak mungkin dilaksanakan dan apabila peserta pelatihan cukup banyak maka diperlukan waktu untuk membahasnya atau (3) materi pelatihan dapat dilakukan secara konsultatif oleh pelatih dengan penyelengara pelatihan kepada peserta pelatihan kepada pengembang kurikulum, organisasi dan pihak lainnya berdasarkan kesepakatan bersama.

Metode pelatihan yang digunakan dalam program pelatihan berdasarkan hasil penelitian ialah metode cermah dan praktek. Dengan menggunakan metode tersebut, peserta dapat menerima materi dengan baik dan kondusif. Dengan demikian dapat dikatakan bahwa metode yang digunakan dalam program pelatihan kepemimpinan ini sudah baik dan mendukung untuk penyelenggaraan program pelatihan kepemimpinan. Hal ini tentunya sesuai dengan pendapat Kamil (2007: 161) dalam 


\section{Learning Community: Jurnal Pendidikan Luar Sekolah, 3 (2), September 2019 - 10}

Nia Mei Istiyani

melaksanakan pelatihan pendekatan yang digunakan adalah pendekatan partisipatif andragogik (model pendekatan orang dewasa), yakni dengan memanfaatkan pengalaman-pengalaman peserta pelatihan sebagai sumber belajar yang terlibat.

Pendanaan merupakan salah satu faktor pendukung berjalannya sebuah program. Sumber biaya yang digunakan dalam pelatihan harus jelas, apakah berasal dari lembaga, penyandang dana, atau dari peserta. Berdasarkan hasil penelitian yang peneliti lakukan di lapangan, pendanaan dalam program pelatihan menjahit di LKP Kartika ini berasal dari biaya pendaftaran warga belajar ketika mereka melakukan pendaftaran pelatihan.

Sarana Prasarana merupakan salah satu komponen penunjang dalam sistem pembelajaran, seperti fasilitas belajar, buku belajar sumber, alat pelajaran, bahan pelajaran dan sebagainya. komponen penunjang berfungsi memperlancar, melengkapi dan mempermudah tercapainya proses pembelajaran secara efektif.

Selain melihat dari kondisi sarana dan prasarana yang ada, peneliti juga melihat dari segi kualitas dan kuantitas. Untuk kualitas mesin dan peralatan yang digunakan di LKP Kartika sudah cukup baik. Pengelola dan instruktur menyatakan bahwa sering dilakukan perawatan digunakan dalam pembelajaran. Sedangkan untuk kuantitas mesin dan peralatan yang ada dalam program kursus menjahit di LKP Kartika sudah mencukupi. Program kursus menjahit tidak hanya memerlukan mesin-mesin saja digunakan untuk menjahit pakaian, bahan dan alat seperti kain, benang, gunting dan sebagainya juga sangat diperlukan. Bahan dan alat yang digunakan oleh warga belajar dalam pembelajaran sudah disediakan semuanya oleh pihak lembaga.

\section{Evaluasi Process}

Evaluasi proses menurut Arikunto dan Safruddin (2009:47) menunjuk pada kegiatan apa yang dilakukan dalam program. Sedangkan menurut Djuju Sudjana (2006: 55) evaluasi program menyediakan umpan balik yang berkenaan dengan efisiensi pelaksanaan program, termasuk didalamnya pengaruh sistem dan keterlaksanaanya. Pada evaluasi proses ini akan menjelaskan tentang aktivitas warga belajar, aktivitas instruktur, strategi pembelajaran, dan partisipasi warga belajar dalam mengikuti program yang dilaksanakan.

Secara keseluruhan, aktivitas warga belajar dalam mengikuti pembelajaran dan interaksi atara warga belajar dan tutor sudah dapat dikatakan baik. Di dalam proses pembelajaran warga belajar mengikuti pembelajaran dengan baik, dan dapat berkomunikasi dengan baik dengan sesama warga belajar dan dengan tutor yang mengampu dalam pembelajaran.

Menurut Lippitt dan Nadler dalam Saleh Marzuki (2012: 177) sebagai soerang penyaji, tutor memiliki tanggung jawab untuk meyakinkan bahwa lingkungan belajarnya akan membantu peserta latihan dalam belajar, dan menyajikan secara jelas. Secara keseluruhan aktivitas tutor dalam proses pembelajaran dapat dikatakan baik. Instruktur dapat melakukan kegiatan pembelajaran dengan baik dalam menyampaikan materi, dan juga tutor dapat memberikan motivasi kepada warga belajar dan dapat berinteraksi dengan warga belajar.

Proses pembelajaran yang terlaksana di LKP Kartika bersifat semi privat, tidak klasikal. Instruktur menguasai semua materi kursus, instruktur mengarahkan kepada tiap individu, sehingga warga belajar merasa lebih luwes untuk bertanya tentang materi yang tidak mereka pahami. Instruktur juga dapat menciptakan suasana pembelajaran yang kondusif dan membuat warga belajar nyaman berada dalam situasi pembelajaran. Instruktur juga selalu memberikan motivasi kepada warga belajar agar bisa lebih bersemangat mengikuti pembelajaran.

Hal ini sesuai dengan pendapat Sudjana menyatakan bahwa tugas-tugas pelatih dalam pembelajaran adalah: (a) membina keakraban antar peserta pelatihan, antar pelatih, dan antara pelatihan dengan pelatih, (b) mengidentifikasi dan menganalisis kebutuhan, sumber-sumber dan kemungkinan hambatan pembelajaran dalam pelatihan, (c) merumuskan tujun pelatihan, (d) menyusun kurikulum pelatihan (bahan/materi, metode, teknik, dan alat evaluasi pembelajaran, (e) menyusun garisgaris program pembelajaran (GBPP), silabus dan satuan acara pembelajaran (SAP) bagi program pelatihan, (f) menyusun modul dan alat bantuan pembeljaran lainnya, (g) 


\section{Learning Community: Jurnal Pendidikan Luar Sekolah, 2 (1), September 2019 - 11}

Nia Mei Istiyani

melakukan pembelajarn secara tatap muka, (h) memberikan pelayanan bantuan belajar jarak jauh bagi peserta pelatihan jarak jauh, (i) memantau proses pembelajaran, (j) membimbing peerta pelatihan dalam penyusunan karya ilmiah, (k) membimbing peserta pelatihan dalam praktik kerja lapangan, (l) menjadi fasilitator, moderator, narasumber, dan pembimbing dalam diskusi, lokakarya, dan atau seminar, (m) menyediakan konsultasi penyelenggaraan dan atau pengelolaan pelatihan, (n) menyusun alat awal tes dan tes akhir pelatihan, (o) memeriksa, mengawasi, dan memeriksa hasil ujian, dan (p) melakukan penilaian program pelatihan.

Nurhalim (2012: 65) strategi pembelajaran adalah rencana dan caracara membawakan pembelajaran agar semua prinsip dasar dapat terlaksana dan semua tujuan pembelajaran dapat dicapai. Strategi yang tutor lakukan dalam pembelajaran sudah sesuai dengan pendapat ahli tersebut. Sebelum menyampaikan materi, tutor terlebih dahulu melihat kemampuan dari warga belajar. Agar saat pelaksanaan penyampaian materi tutor dapat memilih cara yang tepat untuk menyampaikan materi kepada warga belajar agar warga belajar memahami materi tersebut. Selain itu, tutor juga menyampaikan materi dengan sangat detail, perlahan-lahan, dan per tahapan. Sehingga warga belajar dapat dengan mudah menangkap materi yang tutor sampaikan. Strategi pembelajaran yang tutor lakukan ini sudah baik, tepat, dan selaras dengan program kursus yang diadakan untuk warga belajar. Pembelajaran tidak kaku, tidak klasikal seperti kelas. Sehingga warga belajar merasa lebih nyaman dan lebih leluasa dalam mengikuti pembelajaran.

Keikutsertaan warga belajar dalam pembelajaran beragam. Ada yang bersemangat dan mampu menyelesaikan program kursus sampai selesai, dan ada yang berhenti dan tidak melanjutkan program. Sejauh ini, warga belajar yang mengikuti program kursus dapat menyelesaikan program sampai tuntas, bahkan ada yang melanjutkan ke tingkatan kursus selanjutnya. Untuk warga belajar yang tidak menyelesaikan program biasanya mereka memiliki kendala seperti ada kesibukan lain yang tidak dapat ditinggalkan. Hal tersebut juga sesuai dengan pernyataan Fauziarti (2014:183-184) semakin peserta memahami materi yang diberikan pada saat pelatihan, maka akan semakin banyak memberikan pengaruh pada tingkat implementasi perilakunya.

\section{Evaluasi Product}

Suharsimi Arikunto dan Cepi Safruddin (2009:47) evaluasi produk atau hasil diarahkan pada hal-hal yang menunjukkan perubahan yang terjadi pada masukan mentah. Program pelatihan menjahit yang dilaksanakan oleh LKP Kartika telah berhasil melatih warga belajar sehingga terlihat perubahan yang terjadi setalah mengikuti program. Perubahan tersebut dapat dilihat dari hasil yang telah mereka peroleh, yaitu warga belajar memiliki kemampuan menjahit, warga belajar tahu tentang pola, warga belajar bisa mengoperasikan mesin, bertambah kemampuan/ keterampilannya dalam bidang menjahit, dan juga warga belajar bisa membuat pakaian sesuai dengan tingkatan kursus yang diambil.

Direktorat Pembinaan Kursus dan Pelatihan Direktorat Jenderal PAUDNI (2011) menyebutkan, kursus menjahit dan pelatihan bertujuan untuk menumbuhkembangkan kemampuan warga belajar dalam lingkup pekerjaan yang berkaitan dengan menjahit pakaian. Tujuan dari program kursus menjahit di LKP Kartika sudah tercapai. Program telah berjalan sesuai dengan visi dan misi yang ditetapkan oleh lembaga. Visi lembaga antara lain adalah Terwujudnya calon tenaga yang terampil, bermutu, kompeten dan produktif bagi dunia usaha dan industri. Misi lembaga adalah peningkatan pelayanan pelatihan pada masyarakat yang membutuhkan keterampilan standar perusahaan.

Program pelatihan menjahit yang dilaksanakan oleh LKP Kartika telah berhasil mencetak warga belajar sehingga terlihat perubahan yang terjadi setalah mengikuti program. Perubahan tersebut dapat dilihat dari hasil yang telah mereka peroleh, yaitu warga belajar memiliki kemampuan menjahit, warga belajar tahu tentang pola, warga belajar bisa mengoperasikan mesin, bertambah kemampuan/ keterampilannya dalam bidang menjahit, dan juga warga 


\section{Learning Community: Jurnal Pendidikan Luar Sekolah, 3 (2), September 2019 - 12}

Nia Mei Istiyani

belajar bisa membuat pakaian sesuai dengan tingkatan kursus yang diambil.

Dampak dari program pelatihan menjahit menjahit yang diselenggarakan oleh LKP Kartika adalah, warga belajar menjadi memiliki kepercayaan diri dan lebih yakin dengan kemampuan yang telah dimilikinya. Warga belajar jadi mempunyai ide-ide baru yang dapat digunakan untuk membuka usaha. Selain itu warga belajar sudah dapat membuat pakaian untuk digunakan sendiri, dan ada juga warga belajar yang sudah bisa membuka usaha mandiri. Secara keseluruhan dari evaluasi produk ini, tujuan yang telah ditetapkan baik oleh lembaga maupun oleh warga belajar dalam program pelatihan menjahit yang diselenggarakan oleh LKP Kartika sudah dapat tercapai.

Hasil yang diperoleh warga belajar setalah mengikuti program ini adalah warga belajar memiliki kemampuan menjahit, warga belajar tahu tentang pola, warga belajar bisa mengoperasikan mesin, bertambah kemampuan/keterampilannya dalam bidang menjahit, dan juga warga belajar bisa membuat pakaian sesuai dengan tingkatan kursus yang diambil. Dan juga dampak yang dihasilkan dari program pelatihan menjahit ini adalah warga belajar menjadi memiliki kepercayaan diri dan lebih yakin dengan kemampuan yang telah dimilikinya. Warga belajar jadi mempunyai ide-ide baru yang dapat digunakan untuk membuka usaha.Selain itu warga belajar sudah dapat membuat pakaian untuk digunakan sendiri, dan ada juga warga belajar yang sudah bisa membuka usaha sendiri ataupun bekerja di perusahaan garmen..

\section{SIMPULAN}

Berdasarkan hasil penelitian dan pembahasan evaluasi program dengan model CIPP yang ada di LKP Kartika Bawen dapat disimpulkan sebagai berikut: 1) evaluasi konteks (Context),yang terdiri dari dua aspek yaitu kesesuaian program dengan kebutuhan warga belajar dan tujuan program. Semua aspek tersebut sudah tercapai dan sesuai dengan kebutuhan warga belajar dan pihak lembaga. 2) evaluasi masukan (Input), yang terdiri dari tujuh aspek yaitu warga belajar, instruktur, kurikulum, materi pelatihan, metode pelatihan, pendanaan, sarana dan prasarana. Dalam komponen input aspek yang tercapai hanyalah enam aspek, satu aspek yang belum tercapai yaitu aspek instruktur, di LKP Kartika hanya ada satu instruktur yang melatih warga belajar, sehingga instruktur tersebut harus menangani proses pelatihan sendirian. 3) evaluasi proses (Process), yang terdiri dari empat aspek yaitu aktivitas warga belajar, aktivitas instruktur, strategi pembelajaran dan partisipasi warga belajar. Komponen proses di LKP Kartika ini sudah tercapai semuanya sesuai dengan aspek-aspek evaluasi program model CIPP. 4) evaluasi produk (Product), yang terdiri dari tiga aspek yang meliputi ketercapaian tujuan program, hasil belajar dan dampak program. Program pelatihan menjahit di LKP Kartika telah dapat mencapai semua komponen tersebut. LKP Kartika telah mampu membekali warga belajar dengan keterampilan menjahit, yang nantinya keterampilan ini dapat digunakan untuk bekal kehidupannya.

\section{DAFTAR PUSTAKA}

Arikunto, Suharsimi dan Cepi Safrudin Abdul Jabar. 2008. Evaluasi Program Pendidikan. Jakarta: Bumi Aksara.

Direktorat Pembinaan Kursus dan Pelatihan Direktorat Jenderal PAUDNI. 2011. Standar Kompetensi Lulusan Tata Busana.

http://www.infokursus.net/downloa d/2604140806TataBusana23.pdf diunduh 5 Januari 2018.

Eseryel, Deniz. 2002. Approaches to Evaluation of Training : Theory and Practice. Volume 5, No 2. Syracuse University, IDD \& E.

Fauziarti, B.F. \& Sudarsono, F.X. (2014). Efektivitas Pelatihan Kurikulum Pendidikan Anak Usia Dini Di Kecamatan Grabag. Jurnal Pendidikan dan Pemberdayaan Masyarakat, Volume 1 Nomor 2, hal 183 - 184

Kamil, Mustofa. 2007. Model Pendidikan Dan Pelatihan. Bandung: Alfabeta.

Kartika, Ikka. 2011. Mengelola Partisipatif. Bandung: Alfabeta.

Mahmudi, Ihwan. 2011. CIPP: Suatu Model Evaluasi Program Pendidikan. Jurnal At-Ta'dib, Juni 2011, Vol. 6, No. 1.

Marzuki, Saleh. 2012. Pendidikan Nonformal Dimensi dalam Keaksaraan Fungsional, Pelatihan, dan 
Learning Community: Jurnal Pendidikan Luar Sekolah, 2 (1), September 2019 - 13 Nia Mei Istiyani

Andragogi. Bandung : PT Remaja

Rosdakarya. 